\title{
Antimalarial activity of compounds comprising a primary benzene sulfonamide fragment
}

Katherine T Andrews, ${ }^{\mathrm{a}, \mathrm{b}, *}$ Gillian M Fisher, ${ }^{\mathrm{a}, \mathrm{b}}$ Subathdrage DM Sumanadasa, ${ }^{\mathrm{a}, \mathrm{b}}$ Tina Skinner-Adams ${ }^{\mathrm{a}, \mathrm{b}}$, Janina Moeker, ${ }^{\mathrm{a}}$ Marie Lopez ${ }^{\mathrm{a}}$ and Sally-Ann Poulsen ${ }^{\mathrm{a}, *}$

${ }^{a}$ Eskitis Institute for Drug Discovery, Griffith University, Don Young Road, Nathan, Queensland 4111, Australia

${ }^{\mathrm{b}}$ Queensland Institute of Medical Research, Herston, Queensland 4029, Australia "SA-P E-mail: s.poulsen@griffith.edu.au; KTA E-mail: Kathy.Andrews@qimr.edu.au

Nonstandard abbreviations: SAR, structure-activity relationships; SPR, structureproperty relationships; NFF, neonatal foreskin fibroblast; Ro5, rule of 5 violations 


\begin{abstract}
Despite the urgent need for effective antimalarial drugs with novel modes of action no new chemical class of antimalarial drug has been approved for use since 1996. To address this, we have used a rational approach to investigate compounds comprising the primary benzene sulfonamide fragment as a potential new antimalarial chemotype. We report the in vitro activity against Plasmodium falciparum drug sensitive (3D7) and resistant (Dd2) parasites for a panel of fourteen primary benzene sulfonamide compounds. Our findings provide a platform to support the further evaluation of primary benzene sulfonamides as a new antimalarial chemotype, including the identification of the target of these compounds in the parasite.
\end{abstract}

Keywords: sulfonamide, primary sulfonamide, antimalarial, Plasmodium falciparum, SAR, carbonic anhydrase 
Malaria is a major health threat to approximately 3.2 billion people around the world with an estimated 0.8-1.2 million deaths due to malaria each year. ${ }^{1}$ There is currently no licensed malaria vaccine and available drugs, including artemisinin combination therapies (ACTs), are becoming less effective due to parasite resistance and clinical treatment failure. ${ }^{2-7}$ Despite the severity of this problem no new chemical class (chemotype) of antimalarial drug has been approved for use since $1996 .^{8}$ This alarming situation is driving efforts to discover and develop new chemotypes as antimalarial drugs. ${ }^{9}$ In this study we focus on primary benzene sulfonamides as a potential new antimalarial chemotype. In a recent study of a small library of primary benzene sulfonamides several compounds were identified as having an in vitro $\mathrm{IC}_{50}$ of $\sim 1 \mu \mathrm{M}$ against Plasmodium falciparum malaria parasites. ${ }^{10,11}$ Despite this moderate in vitro activity against whole parasites, one compound, 4-(3,4-dichlorophenylureido)thioureido-benzenesulfonamide, (Figure 1) had promising efficacy in a mouse malaria model ( $P$. berghei infected BALB/c mice) with a $50 \%$ inhibitory dose $\left(\mathrm{ID}_{50}\right)$ of $10 \mathrm{mg} / \mathrm{kg}$ compared to the antimalarial drug chloroquine with an $\mathrm{ID}_{50}$ of 5 $\mathrm{mg} / \mathrm{kg}$.

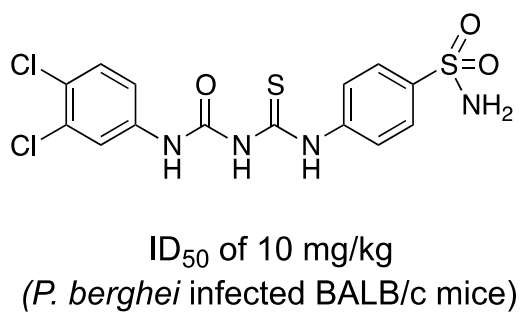

Figure 1. The primary benzene sulfonamide compound 4-(3,4-dichlorophenylureido)thioureidobenzenesulfonamide has antimalarial properties. ${ }^{10,11}$

The sulfonamide functional group has an impressive pharmaceutical pedigree with a proven track record of efficacy and safety. Over 100 sulfonamide-containing drugs are currently on the market across a range of therapeutic areas. ${ }^{12}$ These compounds differ in almost every aspect related to drug-like properties, with no common link except the sulfonamide group within their structure. 
While some 'antibacterial sulfonamides' developed in the 1930s were toxic, an effect historically and incorrectly associated with the primary sulfonamide group (the 'sulfa allergy'), this toxicity is now correctly attributed to the aniline function of these antibacterials and not the sulfonamide group, however the legacy of this misguided connection unfortunately remains. ${ }^{12}$ In terms of malaria, the antimalarial drug sulfadoxine, which is used clinically in combination with pyrimethamine, contains a secondary sulfonamide functional group as well as the aniline toxicophore (Figure 2). Secondary sulfonamides are substituted on the sulfonamide nitrogen contrary to primary sulfonamides, making them structurally different in terms of interactions with potential protein targets, to the extent that primary sulfonamides are a distinct class of compound. ${ }^{13}$

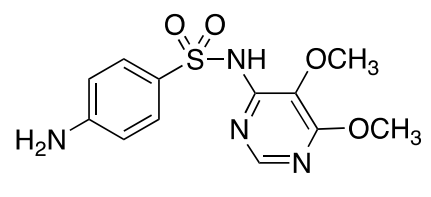

sulfadoxine

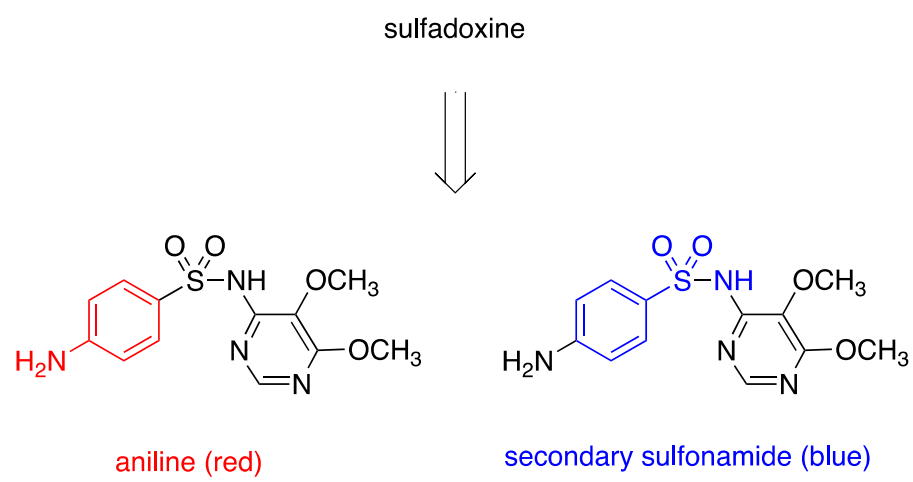

Figure 2. The antimalarial drug sulfadoxine comprises an aniline toxicophore (red) and a secondary sulfonamide group (blue). The secondary sulfonamide chemotype is a distinct structural class from the primary sulfonamide chemotype under investigation in this study.

In this study we examined the in vitro antimalarial efficacy of a panel of primary sulfonamide compounds (1-14) and compared their activity to control compounds where the sulfonamide is replaced by hydrogen $\left(\mathbf{1}^{\prime}-\mathbf{1 0}^{\prime}\right)$. Our aim was to build antimalarial structure-activity and structureproperty relationships (SAR and SPR) around the primary benzene sulfonamide compound class. We have recently reported the synthesis of $S$-linked glucose moieties tethered to a $\mathrm{Ph}-\mathrm{SO}_{2} \mathrm{NH}_{2}$ 
fragment (compounds 1-8, 11-14; Figure 3). ${ }^{14}$ The new compounds of the present study include 9 and 10, comprising $O$-linked carbohydrate moieties tethered to a $\mathrm{Ph}-\mathrm{SO}_{2} \mathrm{NH}_{2}$ fragment, as well as control compounds $\mathbf{1}^{\prime}-\mathbf{1 0} \mathbf{0}^{\prime}$ (Figure 3). Compounds $\mathbf{1}^{\prime}-\mathbf{1 0}$ ' were synthesised from azidobenzene and peracetylated $\beta-S-, \beta-O$ - or $\beta-S O_{2^{-}}$propynyl glucosides in the presence of $\mathrm{CuI}$ and $\mathrm{N}$-bromo succinimide (Scheme 1). Deacetylation of the sugar moieties of control compounds was achieved using 0.05 M sodium methoxide in methanol.
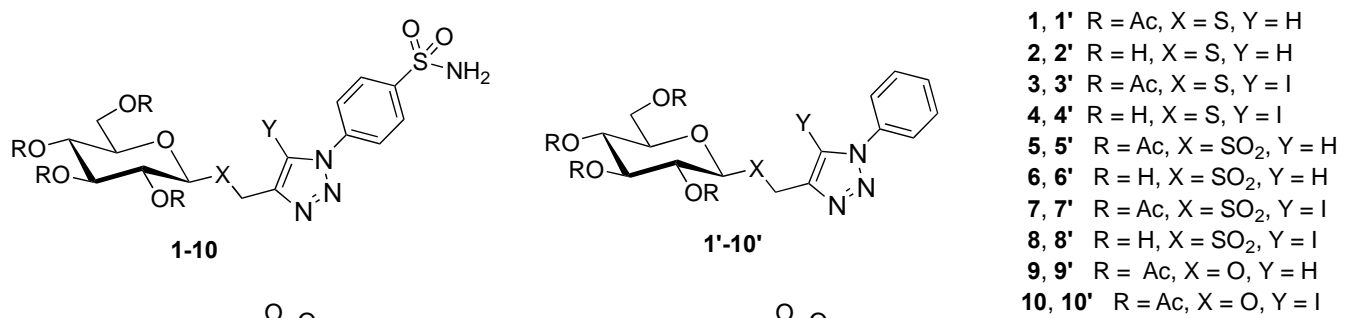

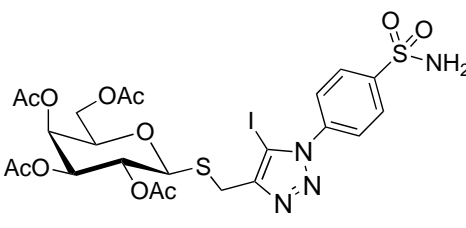

11

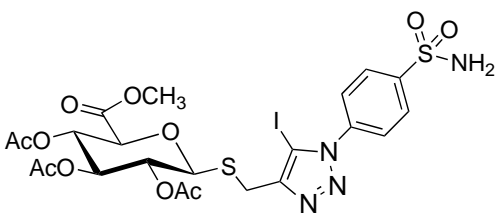

12

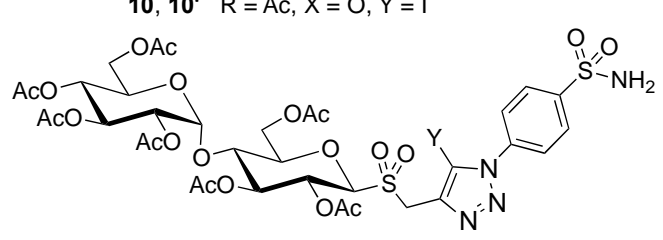

$13 \quad \mathrm{Y}=\mathrm{H}$ $14 Y=I$

Figure 3. Carbohydrate-based primary benzene sulfonamide compounds (1-14) and control compounds, where the sulfonamide moiety is replaced by a hydrogen atom, $\left(\mathbf{1}^{\prime} \mathbf{- 1 0}\right)$.

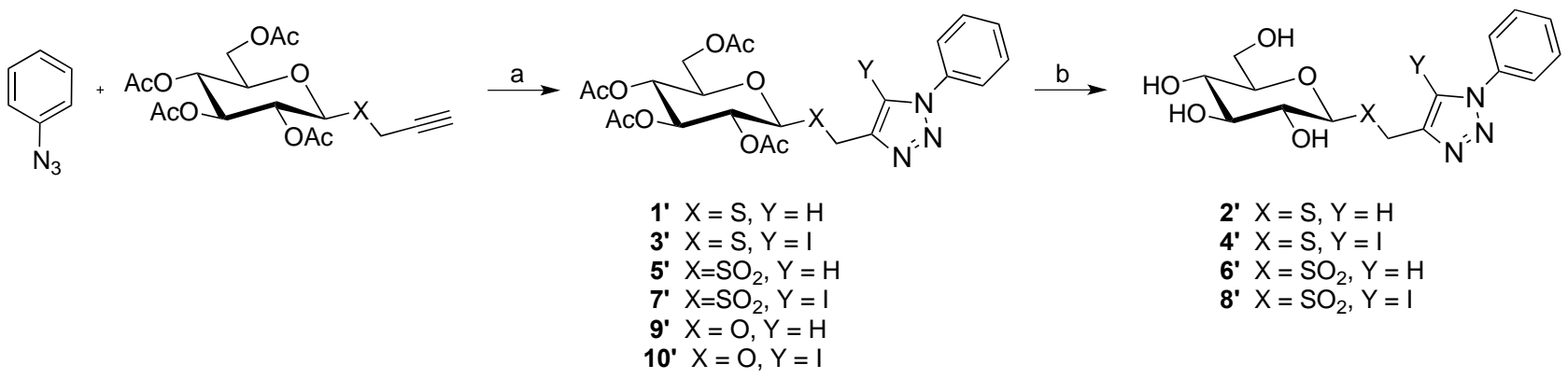

Scheme 1. Synthesis of control compounds $\left(\mathbf{1}^{\prime}-\mathbf{1 0}^{\prime}\right)$.

Reagents and conditions: (a) Peracetylated $\beta-S-, \beta-O-$ or $\beta-S O_{2}$ propynyl glucoside (1.0 equiv), azidobenzene (1.2 equiv), CuI (1.2 equiv), DIPEA (1.2 equiv), NBS (1.2 equiv), THF, room 
temperature, 16 h. (b) $\mathrm{NaOMe}$ in $\mathrm{MeOH}(0.05 \mathrm{M}, \mathrm{pH}$ 12), anhydrous $\mathrm{MeOH}$, room temperature, 30 $\min -2 \mathrm{~h}$.

To determine the in vitro antimalarial activity of primary sulfonamide compounds 1-14, a radiometric growth inhibition assay was employed using a chloroquine-sensitive (3D7) and chloroquine-resistant (Dd2) P. falciparum malaria parasite line (Table 1). A similar SAR trend was observed for both parasite lines. Compounds 2, 5 and $\mathbf{6}$ displayed no activity at the highest concentration tested $(50 \mu \mathrm{M})$, while a further five compounds displayed only modest activity with $\mathrm{IC}_{50}$ values between $\sim 5$ and $50 \mu \mathrm{M}(\mathbf{7}, \mathbf{9 , 1 3 , 8}$ and $\mathbf{1})$. Six compounds had $\mathrm{IC}_{50}$ values less than 6 $\mu \mathrm{M}\left(3,4,11,12,14\right.$ and 10), with the compounds 3 and 4 having the best activity $\left(\mathrm{IC}_{50} \mathrm{~S} \sim 1-2 \mu \mathrm{M}\right.$; Table 1). These glucoconjugate compounds incorporate a range of variable structural features, including a sugar fragment (either glucose, galactose, glucuronic acid or maltose where $\mathrm{R}=\mathrm{Ac}$ or $\mathrm{H})$, a glycosidic linker $\left(\mathrm{X}=\mathrm{S}, \mathrm{O}\right.$, or $\left.\mathrm{SO}_{2}\right)$ and a triazole substituent $(\mathrm{Y}=\mathrm{I}$ or $\mathrm{H})$. Some of the sulfonamide glycosides have been previously shown by us to have anticancer activity in cell based models. $^{14,15}$ Observed trends in antimalarial SAR of compounds $\mathbf{1 - 1 4}$ include (i) the triazole substituted compounds (where $\mathrm{Y}=\mathrm{I}$ ) generally have greater potency than compounds where $\mathrm{Y}=\mathrm{H}$; (ii) the different sugars have minimal affect (compare 3, 11, 12, 14); and (iii) the acetylated sugars $(R=A c)$ either have similar or improved potency over the corresponding free sugars $(R=H)$. A combination of the three substituents ( $\mathrm{R}, \mathrm{Y}$ and $\mathrm{X}$ ) appears to impact on the overall antimalarial activity, however the triazole substituent $(\mathrm{Y}=\mathrm{I}$ or $\mathrm{H}$ ) dominates $\mathrm{SAR}$, followed by the glycosidic linker $\mathrm{X}$ and the sugar $\mathrm{R}$ group, both with lesser effects. Compounds where $\mathrm{Y}=\mathrm{I}$ have the best antimalarial activity and have greater activity than the corresponding compounds where $\mathrm{Y}=\mathrm{H}$, notably $3\left(\mathrm{Y}=\mathrm{I}, \mathrm{IC}_{50} 0.9 \mu \mathrm{M}\right)$ and $\mathbf{4}\left(\mathrm{Y}=\mathrm{I}, \mathrm{IC}_{50} 1.0 \mu \mathrm{M}\right)$ compared to analogues $\mathbf{1}\left(\mathrm{Y}=\mathrm{H}, \mathrm{IC}_{50}\right.$ $31.0 \mu \mathrm{M})$ and $2\left(\mathrm{Y}=\mathrm{H}, \mathrm{IC}_{50}>50 \mu \mathrm{M}\right)$. 
Next, to examine the effect of the sulfonamide group on in vitro antimalarial activity, $P$. falciparum $\mathrm{IC}_{50}$ values were compared for ten compounds comprising $S$-linked (1-8) and $O$-linked (9-10) carbohydrate moieties tethered to a $\mathrm{Ph}-\mathrm{SO}_{2} \mathrm{NH}_{2}$ fragment and ten matched control compounds lacking the sulfonamide group (replaced by a hydrogen atom, $\mathrm{Z}=\mathrm{H})\left(\mathbf{1}^{\prime}-\mathbf{1 0} \mathbf{0}^{\prime}\right)$ (Table 1). Four compounds $\left(\mathbf{3}, \mathbf{4}, \mathbf{1 0}\right.$, and 9) had $\mathrm{IC}_{50}$ values $\sim 4-5$ fold higher when the sulfonamide group was removed (Table 1). In contrast, compound 7 showed little difference in $\mathrm{IC}_{50}$ compared to the corresponding sulfonamide-lacking analogue $\mathbf{7}^{\prime}$. Compound $\mathbf{8}^{\prime}$ was the only compound to have improved activity when the sulfonamide group was removed, with a $\sim 7$-fold lower $\mathrm{IC}_{50}$ than the sulfonamide-containing partner $\mathbf{8}$. The effect of removing the sulfonamide group on compounds $\mathbf{2}$, 5 and $\mathbf{6}$ was not assessed as these compounds and their non-sulfonamide partners all had low biological activity against $P$. falciparum (Table 1).

To assess whether the antimalarial activity of primary sulfonamides examined in this study was selective for the parasite, a cell-based assay using a normal mammalian cell line (neonatal foreskin fibroblast (NFF) cells) was carried out on all primary sulfonamide compounds displaying a $P$. falciparum $\mathrm{IC}_{50} \leq 5 \mu \mathrm{M}$ (Table 1). Six of the seven tested compounds 4, 11, 12, 14, 10 and 7 all had $\mathrm{IC}_{50}$ values $>100 \mu \mathrm{M}$ (the highest concentration tested), while compound $\mathbf{3}$ gave an $\mathrm{IC}_{50} 51.1( \pm 2.8)$ $\mu \mathrm{M}$. The calculated selectivity indices (SI; NFF $\mathrm{IC}_{50} / P$. falciparum $\mathrm{IC}_{50}$ ) were $\geq \sim 40$ for the two most potent antimalarial compounds (3 and $\mathbf{4}$ ). While this is significantly lower than the SI of $>1,000$ seen for the potent antimalarial drug chloroquine (Table 1), the lack of generic cytotoxicity is promising for lead-like antimalarial compounds. 
Table 1 In vitro antimalarial activity of primary benzene sulfonamide compounds $\left(\mathrm{Z}=\mathrm{SO}_{2} \mathrm{NH}_{2}, \mathbf{1 - 1 4}\right)$ and corresponding analogues lacking the sulfonamide group $\left(\mathrm{Z}=\mathrm{H}, \mathbf{1}^{\prime} \mathbf{- 1 0 ^ { \prime }}\right)$. Compounds are listed in descending order of antimalarial activity.

\begin{tabular}{|c|c|c|c|c|c|c|c|c|c|}
\hline \multirow{3}{*}{$\operatorname{Compd}^{a}$} & \multicolumn{4}{|c|}{ Structural features } & \multicolumn{5}{|c|}{$\mathrm{IC}_{50}(\mu \mathrm{M})^{b}$} \\
\hline & \multirow[t]{2}{*}{ sugar } & \multirow[t]{2}{*}{$\mathbf{R}$} & \multirow[t]{2}{*}{$\mathbf{Y}$} & \multirow[t]{2}{*}{$\mathbf{X}$} & \multicolumn{2}{|c|}{$\operatorname{Pf}\left(\mathrm{Z}=\mathrm{SO}_{2} \mathrm{NH}_{2}\right)$} & \multicolumn{2}{|c|}{$\operatorname{Pf}(\mathrm{Z}=\mathrm{H})$} & \multirow{2}{*}{ NFF } \\
\hline & & & & & 3D7 & Dd2 & 3D7 & Dd2 & \\
\hline $3\left(3^{\prime}\right)$ & Glc & Ac & I & $\mathrm{S}$ & $0.9( \pm 0.3)$ & $1.3( \pm 0.2)$ & $4.6( \pm 0.6)$ & $4.8( \pm 2.40)$ & $51.1( \pm 2.8)$ \\
\hline $4\left(4^{\prime}\right)$ & Glc & $\mathrm{H}$ & I & $\mathrm{S}$ & $1.0( \pm 0.5)$ & $1.9( \pm 0.4)$ & $4.9( \pm 1.9)$ & $4.4( \pm 1.40)$ & $>100$ \\
\hline 11 & Gal & $\mathrm{Ac}$ & I & S & $1.4( \pm 0.5)$ & $4.1( \pm 1.5)$ & $\mathrm{ns}$ & ns & $>100$ \\
\hline 12 & GlcOMe & Ac & I & $\mathbf{S}$ & $2.1( \pm 1.2)$ & $6.0( \pm 2.1)$ & ns & ns & $>100$ \\
\hline 14 & Mal & $\mathrm{Ac}$ & I & $\mathrm{SO}_{2}$ & $2.3( \pm 1.8)$ & $2.4( \pm 1.8)$ & ns & ns & $>100$ \\
\hline $10\left(10^{\prime}\right)$ & Glc & Ac & I & $\mathrm{O}$ & $2.8( \pm 1.8)$ & $2.6( \pm 0.7)$ & $10.6( \pm 3.0)$ & $9.4( \pm 4.4)$ & $>100$ \\
\hline $7\left(7^{\prime}\right)$ & Glc & $\mathrm{Ac}$ & I & $\mathrm{SO}_{2}$ & $5.3( \pm 4.6)$ & $7.8( \pm 3.9)$ & $4.7( \pm 1.5)$ & $3.4( \pm 0.3)$ & $>100$ \\
\hline $9\left(9^{\prime}\right)$ & Glc & $\mathrm{Ac}$ & $\mathrm{H}$ & $\mathrm{O}$ & $9.7( \pm 6.1)$ & $11.7( \pm 3.0)$ & $>50$ & $>50$ & nd \\
\hline 13 & Mal & $\mathrm{Ac}$ & $\mathrm{H}$ & $\mathrm{SO}_{2}$ & $20.7( \pm 13.1)$ & $14.7( \pm 1.8)$ & ns & ns & nd \\
\hline $8\left(8^{\prime}\right)$ & Glc & $\mathrm{H}$ & I & $\mathrm{SO}_{2}$ & $28.6( \pm 19.0)$ & $>50$ & $3.8( \pm 0.5)$ & $3.4( \pm 1.0)$ & nd \\
\hline $1\left(1^{\prime}\right)$ & Glc & $\mathrm{Ac}$ & $\mathrm{H}$ & S & $31.0( \pm 10.7)$ & $>25$ & $>50$ & $>50$ & nd \\
\hline
\end{tabular}




\begin{tabular}{ccccc|cc|cc|c|c|}
$\mathbf{2}\left(\mathbf{2}^{\prime}\right)$ & $\mathrm{Glc}$ & $\mathrm{H}$ & $\mathrm{H}$ & $\mathrm{S}$ & $>50$ & $>50$ & $>50$ & $>50$ & $\mathrm{nd}$ & \\
$\mathbf{5}\left(\mathbf{5}^{\prime}\right)$ & $\mathrm{Glc}$ & $\mathrm{Ac}$ & $\mathrm{H}$ & $\mathrm{SO}_{2}$ & $>50$ & $>50$ & $>50$ & $>50$ & nd \\
$\mathbf{6}\left(\mathbf{6}^{\prime}\right)$ & $\mathrm{Glc}$ & $\mathrm{H}$ & $\mathrm{H}$ & $\mathrm{SO}_{2}$ & $>50$ & $>50$ & $>50$ & $>50$ & nd \\
$\mathbf{C Q}$ & - & - & - & - & $0.03( \pm 0.02)$ & $0.1( \pm 0.02)$ & - & - & $>1,000$ \\
\hline
\end{tabular}

${ }^{a}$ Analogues lacking the sulfonamide group are shown in brackets. ${ }^{b}$ Mean $\mathrm{IC}_{50}( \pm \mathrm{SD})$ for primary benzene sulfonamide compounds $\left(\mathrm{Z}=\mathrm{SO}_{2} \mathrm{NH}_{2}\right)$ and corresponding analogues lacking the sulfonamide group $(\mathrm{Z}=\mathrm{H})$ against $P$. falciparum line 3D7 for 3-6 independent experiments (compound 1, $\mathrm{n}=2$ ), each carried out in triplicate wells; Mean $\mathrm{IC}_{50}$ against normal NFF cells for two independent experiments, each carried out in triplicate wells; nd - not determined, ns - not synthesised; Glc - glucose; Gal - galactose; Mal - maltose; CQ, chloroquine. 
Physicochemical property parameter values for the compounds of this study provide a guide to correlate and rationalise SPR with the SAR identified. Log P represents intrinsic lipophilicity and compounds with Log P $<0$ typically have good solubility but poor lipid bilayer permeability. ${ }^{16}$ The use of software tools to calculate $\log \mathrm{P}(\mathrm{cLogP})$ is routine to provide rapid and accurate predictions when used with an awareness of limitations of the software. ${ }^{16-18}$ This relationship correlates well with the poorer activity of the compounds where $\mathrm{X}=\mathrm{SO}_{2}$ as all have a calculated $\log \mathrm{P}(\mathrm{cLog} \mathrm{P})$ value less than 0 , and values lower (by $\sim 1$ ) than the corresponding compound where $\mathrm{X}=\mathrm{S}$. Compounds where $\mathrm{Y}=\mathrm{I}$ have the best antimalarial activity and have greater activity than the corresponding compounds where $\mathrm{Y}=\mathrm{H}$, notably $3\left(\mathrm{Y}=\mathrm{I}_{1} \mathrm{IC}_{50} 0.9 \mu \mathrm{M}, \operatorname{cLog} \mathrm{P}=+1.37\right)$ and $4(\mathrm{Y}=$ I, $\left.\mathrm{IC}_{50} 1.0 \mu \mathrm{M}, \mathrm{cLog} \mathrm{P}=-1.48\right)$ compared to analogues $\mathbf{1}\left(\mathrm{Y}=\mathrm{H}, \mathrm{IC}_{50} 31.0 \mu \mathrm{M}, \mathrm{cLog} \mathrm{P}+0.93\right)$ and 2 $\left(\mathrm{Y}=\mathrm{H}, \mathrm{IC}_{50}>50 \mu \mathrm{M}, \mathrm{cLog} \mathrm{P}-1.99\right)$. Interestingly, the effect of the triazole substituent $\mathrm{Y}=\mathrm{I}$ on activity appears independent of cLog P as compounds $\mathbf{3}$ and $\mathbf{4}$ have opposing Log P values and likely opposing membrane permeability, yet almost identical $\mathrm{IC}_{50} \mathrm{~S}$ at $1 \mu \mathrm{M}$ or less. However, it is important to note that while the human serum used for parasite culture is heat treated, any residual esterase activity ${ }^{19,20}$ may hydrolyze the acetate groups $(\mathrm{R}=\mathrm{Ac})$ of sugars converting compounds $\mathbf{3}$, $\mathbf{7}$ and $\mathbf{1}$ to the less permeable free sugars $(\mathrm{R}=\mathrm{H})$, compounds $\mathbf{4 , 8}$ and $\mathbf{2}$, respectively. Sulfonamide compounds $3,4,10$ and 9 are predicted to have better cell membrane permeability when the primary sulfonamide is removed to give $3^{\prime}, 4^{\prime}, \mathbf{1 0}^{\prime}$ and $\mathbf{9}^{\prime}$ respectively, so the $\sim 5$-fold reduction in antimalarial activity is indicative of a target based effect.

In summary, lead antimalarial compounds should possess appropriate pharmacological and toxicological characteristics as well as tractable preparation to enable successful development targeting both drug-sensitive and drug-resistant parasite lines. Several compounds of this study fulfill these basic requirements, most notably primary benzene sulfonamide compounds $\mathbf{3}$ and $\mathbf{4}$. In addition, our SAR studies support the role of the primary benzene sulfonamide chemotype on these compounds as conferring antimalarial activity. While promising lead-like compounds have been 
identified in this study, it is also evident that improving the membrane permeability and other biopharmaceutical parameters for these compounds will be important in future development of compounds for oral delivery with improved potency and selectivity. While the target for these compounds in the parasite is not yet known, the malaria parasite CA is possible candidate. Many primary sulfonamide compounds are known to target CA enzyme activity. CA enzymes maintain an important physiological equilibrium: the hydration of carbon dioxide $\left(\mathrm{CO}_{2}\right)$ to bicarbonate anion $\left(\mathrm{HCO}_{3}{ }^{-}\right)$and a proton $\left(\mathrm{H}^{+}\right) .{ }^{23}$ Targeted inhibition of specific human CA isozymes to disrupt this equilibrium has successfully treated several human pathologies. ${ }^{23}$ The primary sulfonamide moiety is in the structure of drugs where the mechanism of action is attributed to CA inhibition. ${ }^{23}$ The CAs from Helicobacter pylori, Candida albicans, Candida glabrata, Cryptococcus neoformans and Brucella suis are essential for pathogen growth and have proven susceptible to inhibition with several compound classes including primary sulfonamide compounds. ${ }^{24}$ CAs from these pathogens are now recognised as potential anti-infective drug targets. ${ }^{24}$ The malaria parasite CA (PfCA) was shown to be inhibited by 4-(3,4-dichlorophenylureido)thioureido-benzenesulfonamide $\left(K_{\mathrm{i}}=0.18 \mu \mathrm{M}\right.$, Figure 1), and is a putative target of antimalarial primary sulfonamide compounds described herein. ${ }^{10}$ We are currently working to express $P$. falciparum $\mathrm{CA}$ to further investigate this hypothesis. Our findings provide a platform to support the further evaluation and development of primary benzene sulfonamides for discovery of novel chemotypes supporting antimalarial drug development. Once characterised these molecules may also provide specific probes to further aid identification of the target of these compounds in the parasite.

Supplementary Material: Experimental details for synthetic procedures and biological methods, ${ }^{1} \mathrm{H}$ and ${ }^{13} \mathrm{C}$ NMR spectra of new compounds and predicted physicochemical properties of all compounds.

Acknowledgements: This work was supported by the Australian Research Council (FF110100185 to SAP and FT0991213 to KTA) and the Australian National Health and Medical Research Council 
(NHMRC1038967 to GMF). We thank Jason Morris for the original synthesis of $S$-glycosides and Marc Campitelli for assistance with QikProp software. We acknowledge the Australian Red Cross Blood Service for the provision of human blood and sera.

\section{References}

1. Murray, C. J.; Rosenfeld, L. C.; Lim, S. S.; Andrews, K. G.; Foreman, K. J.; Haring, D.; Fullman, N.; Nacghavi, M.; Lozano, R.; Lopez, A. Lancet 2012, 379, 413.

2. Dondorp, A. M.; Yeung, S.; White, L.; Nguon, C.; Day, N. P. J.; Socheat, D.; von Seidlein, L. Nat. Rev. Microbiol. 2010, 8, 272.

3. Dondorp, A. M.; Nosten, F.; Yi, P.; Das, D.; Phyo, A. P.; Tarning, J.; Lwin, K. M.; Ariey, F.; Hanpithakpong, W.; Lee, S. J.; Ringwald, P.; Silamut, K.; Imwong, M.; Chotivanich, K.; Lim, P.; Herdman, T.; An, S. S.; Yeung, S.; Singhasivanon, P.; Day, N. P. J.; Lindegardh, N.; Socheat, D.; White, N. J. N Engl J Med 2009, 361, 455.

4. Noedl, H.; Se, Y.; Schaecher, K.; Smith, B. L.; Socheat, D.; Fukuda, M. M. N. Engl. J. Med. 2008, 359, 2619.

5. Noedl, H.; Socheat, D.; Satimai, W. N. Engl. J. Med. 2009, 361, 540.

6. $\quad$ Becer, C. R.; Richard, H.; Ulrich, S. S. Angew. Chem. Int. Ed. 2009, 48, 4900.

7. Phyo, A. P.; Nkhoma, S.; Stepniewska, K.; Ashley, E. A.; Nair, S.; McGready, R.; ler Moo, C.; Al-Saai, S.; Dondorp, A. M.; Lwin, K. M.; Singhasivanon, P.; Day, N. P.; White, N. J.; Anderson, T. J.; Nosten, F. Lancet 2012, 379, 1960.

8. $\quad$ Ekland, E. H.; Fidock, D. A. Int. J. Parasitol. 2008, 38, 743.

9. Wells, T. N. C.; Alonso, P. L.; Gutteridge, W. E. Nat. Rev. Drug Discov. 2009, 8, 879.

10. Krungkrai, J.; Krungkrai, S. R.; Supuran, C. T. Bioorg. Med. Chem. Lett. 2008, 18, 5466.

11. Krungkrai, J.; Krungkrai, S. R.; Supuran, C. T. Curr. Top. Med. Chem. 2007, 7, 909.

12. Smith, D. A.; Jones, R. M. Curr. Opin. Drug Disc. Dev. 2008, 11, 72.

13. Capasso, C.; Supuran, C. T. J. Enzyme Inhib. Med. Chem. 2013, Posted online on 29 Apr 2013.

14. Morris, J. C.; Chiche, J.; Grellier, C.; Lopez, M.; Bornaghi, L. F.; Maresca, A.; Supuran, C. T.; Pouyssegur, J.; Poulsen, S.-A. J. Med. Chem. 2011, 54, 6905.

15. Lounnas, N.; Rosilio, C.; Nebout, M.; Mary, D.; Griessinger, E.; Neffati, Z.; Chiche, J.; Spits, H.; Hagenbeek, T. J.; Asnafi, V.; Poulsen, S.-A.; Supuran, C. T.; Peyron, J.-F.; Imbert, V. Cancer Letters 2013, 333, 76. 
16. Kerns, E. H.; Di, L. In Drug-like Properties: Concepts, Structure Design and Methods: from ADME to Toxicity Optimization; Kerns, E. H., Di, L., Eds.; Academic Press: London, 2008, pp. 260.

17. Salmon, A. J.; Williams, M. L.; Wu, Q. K.; Morizzi, J.; Gregg, D.; Charman, S. A.; Vullo, D.; Supuran, C. T.; Poulsen, S.-A. J. Med. Chem. 2012, 55, 5506.

18. Carroux, C. J.; Moeker, J.; Motte, J.; Lopez, M.; Bornaghi, L. F.; Katneni, K.; Ryan, E.; Morizzi, J.; Shackleford, D. M.; Charman, S. A.; Poulsen, S.-A. Bioorg. Med. Chem. Lett. 2013, 23, 455 .

19. Kragh-Hansen, U.; Chuang, V. T. G.; Otagiri, M. Biological \& Pharmaceutical Bulletin 2002, 25,695 .

20. Cordova, J.; Ryan, J. D.; Boonyaratanakornkit, B. B.; Clark, D. S. Enzyme Microb. Technol. 2008, 42, 278.

21. Schrödinger. Schrödinger LLC: New York, 2005; http://www.schrodinger.com. 2012.

22. Schrödinger. QikProp 3.5 User Manual, Schrödinger Press 2012.

23. Supuran, C. T. Nat. Rev. Drug Discov. 2008, 7, 168.

24. Capasso, C.; Supuran, C. T. Expert Opin. Ther. Patents 2013, 23, 693. 